\title{
Activity-dependent plasticity in spinal cord injury
}

\author{
James V. Lynskey, PhD, PT; ${ }^{1-2}$ Adam Belanger, MS; ${ }^{1,3}$ Ranu Jung, PhD ${ }^{1,3 *}$ \\ ${ }^{1}$ Center for Adaptive Neural Systems, Ira A. Fulton School of Engineering, Arizona State University, Tempe, AZ; \\ ${ }^{2}$ Department of Physical Therapy, Arizona School of Health Sciences, A.T. Still University, Mesa, AZ; ${ }^{3}$ Harrington \\ Department of Bioengineering, Ira A. Fulton School of Engineering, Arizona State University, Tempe, AZ
}

\begin{abstract}
The adult mammalian central nervous system (CNS) is capable of considerable plasticity, both in health and disease. After spinal neurotrauma, the degrees and extent of neuroplasticity and recovery depend on multiple factors, including the level and extent of injury, postinjury medical and surgical care, and rehabilitative interventions. Rehabilitation strategies focus less on repairing lost connections and more on influencing CNS plasticity for regaining function. Current evidence indicates that strategies for rehabilitation, including passive exercise, active exercise with some voluntary control, and use of neuroprostheses, can enhance sensorimotor recovery after spinal cord injury (SCI) by promoting adaptive structural and functional plasticity while mitigating maladaptive changes at multiple levels of the neuraxis. In this review, we will discuss CNS plasticity that occurs both spontaneously after SCI and in response to rehabilitative therapies.
\end{abstract}

Key words: central nervous system, electrical stimulation, exercise, neuromuscular, neuroprostheses, neurotrophic factors, plasticity, recovery, rehabilitation, spinal cord injury, therapy.

\section{INTRODUCTION}

Spinal cord injuries (SCIs) disrupt both axonal pathways and segmental spinal cord circuitry, producing severe impairments of motor, sensory, and autonomic function at and below the level of the injury. However, significant recovery can and often does occur in the first year following SCIs classified as incomplete [1-4]. The amount and extent of recovery depend on multiple factors, including the level and extent of injury, postinjury medical and surgical care, and rehabilitative interventions. Rehabilitative therapies, such as intense repetitive training ("massed practice") [5] and locomotor training [6-7], have been shown to promote recovery after incomplete SCI in humans. Although the mechanisms mediating this recovery are not fully understood, activity-dependent plasticity likely plays a major role.

In this review, we discuss central nervous system (CNS) plasticity after SCI, occurring both spontaneously after injury and in response to rehabilitative therapies. Plasticity is a term widely used to describe a variety of biological phenomena. Merriam-Webster's Medical Dictionary defines plasticity as "the capacity for continuous alteration of the neural pathways and synapses of the living brain and nervous system in response to experience or injury" (http://medical.merriam-webster.com/). Furthermore, these plastic changes underlie learning, memory, and recovery from neural injury [8]. Several published reports support the view that the CNS is capable of

\footnotetext{
Abbreviations: $\mathrm{BDNF}=$ brain-derived neurotrophic factor, CNS = central nervous system, ESCS = epidural spinal cord stimulation, FES = functional electrical stimulation, FNS = functional neuromuscular stimulation, SCI $=$ spinal cord injury, TrkB = tyrosine kinase B.

* Address all correspondence to Ranu Jung, PhD; Center for Adaptive Neural Systems, Arizona Sate University, PO Box 879709, Tempe, AZ 85287-9709; 480-965-9052; fax: 480-727-7624. Email: ranu.jung@asu.edu

DOI: 10.1682/JRRD.2007.03.0047
} 
significant plasticity after SCI and that rehabilitative interventions after neural injury affect this plasticity at several levels [8-10]:

- Behavioral (recovery of sensory, motor, or autonomic function).

- Physiological (normalization of reflexes, strengthening of motor-evoked potentials).

- Structural/neuroanatomical (axonal sprouting, dendritic sprouting, neurogenesis).

- Cellular (synaptogenesis, synaptic strengthening).

- Molecular (up-regulation of neurotransmitters and neurotrophic factors, alterations in gene expression).

\section{SPONTANEOUS PLASTICITY AFTER SCI}

Based mostly on the results of studies using animal models, reorganization of the CNS, including synaptic plasticity, axonal sprouting, and cellular proliferation, has long been known to spontaneously occur following spinal cord lesions [11-20]. This reorganization occurs in the spinal cord circuitry caudal to injury, in the spinal cord around the lesion, in the spinal cord rostral to injury, and in supraspinal structures.

In 1929, Pike and colleagues observed spontaneous hind limb recovery after spinal cord hemisection in cats and proposed that "the mechanism which takes over control of movements of the limb lying below the level of the lesion includes motor fibers coming down on the opposite side of the spinal cord, and commissural neurons lying in the spinal cord below the level of the lesion" [21]. A recent study reported that after midthoracic dorsal hemisection, the corticospinal tract collaterals of the hind limb sprout into the cervical gray matter where they contact descending propriospinal neurons and a new intraspinal circuit is formed [22]. Additionally, the affected propriospinal neurons arborize on lumbar motoneurons so that the detoured corticospinal signals reach their original targets [22]. Over time, these new connections selfprune to include only circuits that bridge the lesion site. At the level of the lesion, descending efferent corticospinal, raphespinal, reticulospinal, and coeruleospinal axons sprout and/or regenerate into the lesion cavity after incomplete contusive SCIs [18,23]. Additionally, cellular proliferation occurs around the lesion-producing oligodendrocytes and astrocytes, possibly replacing some of the cells lost during injury and remyelinating axons $[17,20,24]$. Thus the adult CNS can create novel path- ways and substrates to reestablish lost supraspinal control to the spinal cord caudal to injury, possibly mediating some of the spontaneous recovery observed.

Reorganization of cortical maps has also been reported to occur spontaneously after both complete and incomplete SCIs in humans [25-27] and rodents [22]. The underlying mechanisms are hypothesized to be similar to those mediating reorganization after cortical injury, including disinhibition of latent cortical connections and axonal sprouting in multiple levels of the neuraxis $[9,22,28]$. Another mechanism may be injury-induced structural plasticity in the dendritic spines of cortical motoneurons. For example, changes in dendritic spine density and morphology in neurons of the motor cortex have been observed to occur over 3 days to 2 weeks after a fourth cervical spinal overhemisection in rodents [29]. Thus spontaneous plasticity after SCI does not appear to be limited to the spinal cord but can occur in supraspinal structures. However, how these cortical changes affect sensorimotor function, if at all, is not currently known.

As would also be expected, SCIs (both complete and incomplete) also produce considerable changes in the spinal cord circuitry caudal to injury. At the morphological level, SCIs can produce significant changes in dendritic morphology and marked loss of dendritic branching [3032]. Structural plasticity at the dendritic level affects the integration of synaptic inputs to the neurons and can hence profoundly influence the electrophysiological responses of the neurons and therefore the neural circuitry [33-34]. After experimental SCI in rodents, one can observe increased group Ia afferent excitatory postsynaptic potentials, alterations in $\mathrm{H}$ reflexes, and changes in passive and active motoneuron resting membrane potentials, including development of persistent ionic current-based plateau-potentials [35-39]. In addition, spontaneous sprouting of afferent axons, including calcitonin gene-related protein positive $C$ fibers, has also been well documented around and below the lesion site in rodents, which contributes to the development of hyperreflexia and autonomic dysreflexia [19,40-41]. These anatomical and electrophysiological changes indicate that spinal cord circuitry with impaired or absent descending supraspinal and spinal input is more excitable by peripheral stimulation and may partially explain the exaggerated reflex responsiveness, hypertonicity, and autonomic disturbances that occur after SCIs.

Thus, from days to weeks after experimental SCI in animal models, spontaneous cellular, structural, and 
electrophysiological changes occur along the entire neuraxis. Evidence supports similar changes after SCI in humans [42]. Some of these spontaneous changes appear to be adaptive (promoting recovery and providing targets for therapy) and some appear to be maladaptive (inhibiting recovery and impairing function). Rehabilitative strategies could be used to enhance adaptive plasticity and/or mitigate maladaptive plasticity to enhance recovery after SCI.

\section{ENHANCING CNS PLASTICITY AND RECOV- ERY USING REHABILITATION STRATEGIES AFTER SCI}

The idea that neural activation may lead to anatomical and chemical changes in the CNS was first postulated in the 19th and early 20th centuries by influential figures such as Darwin, Ramón y Cajal, and Hebb. Further corroboration of this idea has occurred through numerous studies conducted over the last 50 or more years $[8,43]$ and has led to strategies to elicit activity-dependent plasticity to promote recovery after spinal neurotrauma [1]. As summarized in the Figure, rehabilitative therapies can promote plasticity both rostral and caudal to injury in the spinal cord by activating the nervous system and influencing multiple substrates. One approach to activating the

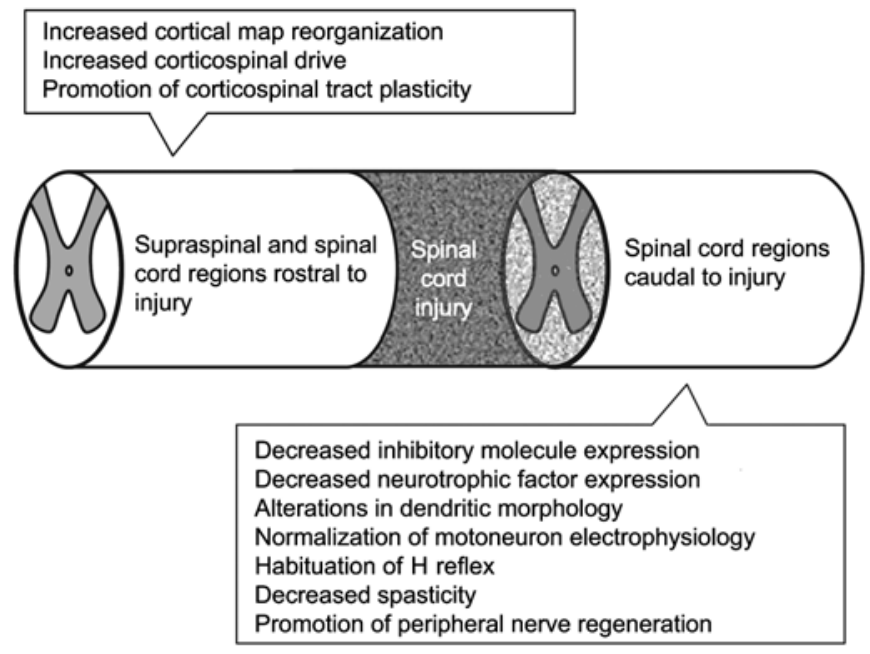

Figure.

Activity-dependent plasticity after spinal cord injury (SCI). Following SCI, rehabilitative therapies can promote significant structural and functional plasticity within central nervous system both rostral and caudal to injury. nervous system, particularly in the context of the sensorimotor system, is to use rehabilitative strategies that include stimulating somatic sensory afferents and activating functional movements. In this section, we review three such strategies for providing therapy to promote plasticity and recovery: (1) use of passive exercise, (2) use of active modes of exercise, and (3) use of neuroprostheses for electrical activation of motoneurons and sensory afferents.

\section{Passive Exercise}

Passive exercise can be used for inducing functional ranges of joint motion and sensory feedback to maintain or improve neuromuscular function after complete or incomplete SCIs, respectively. Motorized cycling is one such approach that both research laboratories and clinical settings now use to provide passive exercise. An advantage of this approach is that performing the exercise does not require any volitional control and can be initiated at early time points after injury.

Neural circuits within the spinal cord form reflex pathways that work together to help control the coordination of complex movements. These reflex pathways are not only triggered by sensory afferents but are also modulated by supraspinal inputs. After SCI, supraspinal control is impaired because of the tissue damage described earlier, thereby leaving the spinal neural circuitry to be driven primarily by the peripheral sensory input [44-45]. This shift toward peripheral control may contribute to the development of spasticity and abnormal muscle tone. An important sensory input to the spinal cord neural circuitry is from the group Ia muscle spindle afferents. Stretching of a limb muscle caused by joint movement activates the $\mathrm{H}$ reflex via the group Ia afferents. The reflex activation recruits synergistic muscles and inhibits antagonists [46]. Passive exercise activates the $\mathrm{H}$ reflex and, through repetition training, appears to be able to "condition" the caudal spinal circuitry to "normalize" specific spinal reflexes in the absence of supraspinal control [47]. Passive exercise has been provided with use of bicycles and robotic assistance [48]. Use of a motorized bicycle in rats $[37,47,49]$ and in humans [50-51] causes some normalization of motoneuron electrophysiology, causes habituation of the $\mathrm{H}$ reflex and decreased spasticity, and can influence dendritic morphology [32]. However, at least for humans, continued cycling is required to maintain the effects. Most likely, exercise paradigms that promote activation of load receptors that trigger some of the reflex 
pathways will be beneficial [4,45,52-53], as will approaches that include plantar cutaneous stimulation $[4,54]$. Thus continued research to increase our understanding of CNS plasticity mediated by passive exercise after SCI could help determine if passive exercise alone can lead to improved sensorimotor function.

\section{Active Exercise}

Another rehabilitation strategy following SCI is active exercise. This exercise approach requires subjects to perform assisted or unassisted active movements using varying degrees of supraspinal and/or segmental spinal control. Multiple approaches have been used to provide active exercise in people with incomplete SCIs. These approaches include locomotor training (manual-assisted and robot-assisted partial weight-supported treadmill training, as well as overground locomotion), repetitive upper-limb training, and general exercise/environmental enrichment. Using active voluntary exercise as a rehabilitation technique targets harnessing the neuroplasticity seen with passive exercise but with added benefits. Voluntary exercise elicits not only functional ranges of joint motion but also functional activation of muscles and multiple modes of afferent stimulation.

Increasing postinjury activity via locomotor training has been shown to improve motor recovery, although some questions remain about the role and degree of specificity of locomotor training needed to achieve significant recovery [55]. In rodents, exercise and treadmill training can support partial recovery of hind locomotion [10,5659] and sensation [57] after incomplete SCIs. Studies conducted on spinal cord-transected cats suggest that recovery after locomotor training is task-specific and relies on sensory feedback mechanisms [60-61].

In rodent and feline models of thoracic SCI, the effects of locomotor training on neuroplasticity have been observed at the cellular level. The training decreases expression of inhibitory molecules [62], increases expression of neurotrophic factors [57], and alters electrophysiological properties in the lumbar enlargement $[10,37]$. These changes might mitigate some of the spontaneously occurring maladaptive plasticity that can cause spasticity and enable the isolated (partial or complete) spinal cord to produce locomotion with little or no descending control.

Locomotor training, both overground and on a treadmill using partial body weight support, has also been shown to promote recovery in humans with incomplete
SCIs [4,6-7,9,44,63-69]. Evidently, the active exercise paradigm mediates plasticity at multiple levels of the neuraxis including the cortex, descending supraspinal motor pathways, and spinal cord circuitry caudal to injury.

In humans, intense repetitive training (massed practice) after a cervical spinal injury and robotic locomotor training after a thoracic spinal injury appear to promote cortical plasticity as cortical map reorganization [5,7071]. As with spontaneously occurring cortical plasticity, the substrates and implications of this activity-dependent cortical reorganization after SCI are unclear. However, recent data from neurologically intact nonhuman primates indicate that activity can reorganize the motor cortex, such that cortical motoneurons "learn" to control additional muscles and produce novel movements when stimulated [72]. Rehabilitative therapies may possibly promote a "rewiring" of the cortex to bypass pathways interrupted by an incomplete SCI, thereby reestablishing supraspinal control of caudal circuitry using novel supraspinal-spinal circuits. In fact, locomotor training on a treadmill after incomplete SCI in humans promotes improved corticospinal drive to muscles of the lower limb that correlates with improved locomotor function [73-74]. This increased corticospinal drive could come from plasticity occurring in the cortex (see aforementioned data) or in the descending pathways themselves. In rodents after incomplete SCI, increased activity via enriched environment promotes plasticity in spared corticospinal but not raphespinal or rubrospinal axons [75].

Based on studies in animal models, a possible molecular mechanism has been proposed for the neuroplasticity events known to occur because of voluntary exercise after SCI. Brain-derived neurotrophic factor (BDNF) and its associated receptor, tyrosine kinase B (TrkB), may be the primary modulators of a biochemical cascade resulting in neuroplasticity. BDNF is known to synthesize and phosphorylate synapsin 1 [16,76], a phosphoprotein responsible for neurotransmitter release and axonal growth [77-78]. In rodent models of SCI, increased expression of BDNF, TrkB, and synapsin 1

\footnotetext{
*Lynskey JV, McAtee M, Dai HN, Iarikova E, Hamers FP, Bregman BS. Environmental enrichment promotes recovery of forelimb movements and supraspinal pathway plasticity after cervical spinal cord injury in adult rats [abstract]. In: 2005 Proceedings of the 11th International Symposium on Neural Regeneration; 2005 Dec 14-18; Pacific Grove, California.
} 
occurred in the spinal cord starting in the secondary phase and persisting in the chronic phase following injury after voluntary exercise [79].

In rats with SCI following voluntary exercise, further elevation of BDNF levels was found in skeletal muscles and in the innervating level of the spinal cord [80]. Other research has also found that BDNF can be retrogradely transported through motoneurons from the skeletal muscles to the spinal cord [81-82]. These data suggest that up-regulation of BDNF expression may have a causal relationship with neuroplasticity, neuronal growth, and functional recovery and that increased recovery results from voluntary exercise. BDNF and other neurotrophic factors have been hypothesized to facilitate neuronal plasticity in an autocrine or paracrine fashion [83]. This neurotrophic up-regulation is not only activity-dependent but also activity-specific, which reinforces the notion that differential recovery results from differential voluntary exercise regimes [57]. All the nuances of BDNF up-regulation appear to coincide with the recovery observed following rehabilitation after incomplete SCI. This finding suggests that neuroplasticity can occur through a BDNFmediated pathway [80,84-88].

Voluntary exercise, as just described, shows promise as an effective promoter of recovery and activity-dependent plasticity throughout the neuraxis after incomplete SCI. In future multifaceted treatment, strategies could be used to maximize the effectiveness of rehabilitative therapies. Passive exercise, such as motorized cycling, could be administered early postinjury (to promote plasticity caudal to injury and possibly mitigate spasticity) followed by more active exercise (to promote plasticity both rostral and caudal to injury). However, voluntary exercise can only be performed by individuals who have some preexisting level of motor function, which limits rehabilitative interventions to those with incomplete SCIs.

\section{Neuroprostheses for Rehabilitation}

Use of neuroprostheses is another rehabilitative strategy that combats the limitations of both passive and active voluntary exercise. Neuroprostheses use electrical stimulation to activate neural structures [89]. In applications in people with SCI, functional electrical stimulation (FES) is one neuroprosthetic approach to improve locomotor function that stimulates the peroneal nerves to elicit a flexion withdrawal reflex and thereby cause limb movement [90]. A second approach is functional neuromuscu- lar stimulation (FNS). It stimulates multiple leg muscles at their motor points in an appropriate sequence to produce coordinated functional movements, such as grasping, standing, or rhythmic leg movement [91-95]. A third approach called epidural spinal cord stimulation (ESCS) stimulates the dorsal aspect of the spinal cord at a particular spinal level using implanted electrodes [96-98].

When used in a paradigm for motor therapy, neuroprostheses seek to enhance standard therapist-provided rehabilitation by generating active muscle contractions, generating improved movement patterns, and reducing the physical demands on the therapists. FES therapy, which elicits the flexion withdrawal reflex to assist persons with an incomplete SCI bring their leg into the swing phase of gait, has resulted in a carryover of increased functional mobility and speed, decreased effort, and improved intralimb coordination during unstimulated overground locomotion [90,99-104]. Electrical stimulation of sensory afferents alone may also contribute to recovery after incomplete SCI [105].

Since the flexion withdrawal reflex habituates, its use in a repetitive therapy paradigm has some inherent limitations. Use of FNS to stimulate the muscles via the motor points attempts to overcome this limitation. As therapy, FNS can decrease the fatigability of muscles after SCI [106-107], reverse muscle atrophy, and increase bone density [108]. FNS, along with cycling exercise, may also promote recovery in individuals with chronic incomplete SCIs [109-110]. Since muscles fatigue with ongoing stimulation and have nonlinear properties, using an adaptive control approach would help tailor the stimulation to the individual muscle properties and automatically adjust stimulus strength for repeatable movements [111-113].

ESCS, which has traditionally been used as a modality for pain control [114], has been shown to reduce spasticity after SCI [97-98,115]. Appropriate levels of ESCS can promote stepping movements and even locomotion in humans [96,116-118] and animals (rodents and cats) [119-120] with SCIs.

How electrical stimulation likely promotes recovery remains unclear, but the mechanisms may include plastic changes at the cellular/molecular and circuitry levels. The sensory afferent input provided by peripheral electrical stimulation likely provides drive to the spared CNS. In decerebrate cats, electrical stimulation of hind limb muscles can cause reflex withdrawal of the contralateral hind limbs [121] and direct electrical stimulation of sensory afferents 
in the dorsal root entry zone can activate the lumbar spinal pattern generator [122]. ESCS appears to produce significant plastic changes. These changes include altering the electrophysiological properties of spinal motor pattern-generating circuitry [115,123-124], altering amino acid neurotransmitter levels in the spinal cord (glycine and taurine) [125], and altering blood flow (both centrally and peripherally) [126-128].

Electrical stimulation may also trigger the BDNFmediated mechanism of recovery described earlier. Direct electrical stimulation to both motor [129-131] and sensory [132] peripheral neuron cell bodies increases BDNF and TrkB expression in those cells and leads to axonal regeneration. Additionally, electrical stimulation can partially restore segmental spinal reflex responses in the lumbar spinal cord, in particular the H reflex [133], that are altered by thoracic SCI [134]. For continued examination of the circuit level and cellular mechanisms, a rodent-model for FNS therapy has recently been developed [135-136]. Short-term FNS therapy in a rodent model of contusion injury also results in a carryover into improved symmetry of treadmill walking [137].

Thus electrical stimulation, used alone or combined with active exercise, promotes recovery and plasticity after neural injury. Multiple characteristics of therapeutic electrical stimulation (including being noninvasive, not requiring volitional muscle control, producing graded muscle contractions, and producing functional ranges of motion) allow for its use as both an early intervention (possibly along with passive exercise) and a chronic intervention (along with locomotor training).

\section{ENHANCING CNS PLASTICITY AND RECOV- ERY USING MULTIFACETED TREATMENT APPROACHES AFTER SCI}

Scientists and clinicians have widely theorized that given the myriad of issues preventing recovery of function after SCI, multifaceted treatment approaches will be most successful [1]. In fact, the goals of most rehabilitative strategies are to complement and optimize the more invasive transplantation and pharmacological treatment strategies required to "cure" SCI. These goals are reasonable considering that the data from initial treatment approaches of combined locomotor training and pharmacological interventions after complete SCI in cats pro- duced favorable results [44]. However, recent studies using similar approaches after incomplete SCIs in rodents have not produced the anticipated additive results. In rodents, combined treatment involving passive motorized cycling and stromal cell transplants did not improve plasticity or sensorimotor behavioral recovery after incomplete contusive injury [138]. In addition, electrical stimulation combined with peripheral nerve grafts does not improve rubrospinal tract regeneration after partial transection [139]. Furthermore, treatment combining robotic-assisted locomotor training on a treadmill and quipazine administration does not enhance recovery of locomotion [140]. Thus despite multiple studies in animal models of SCI and tremendous advances in our understanding of the postinjury response process, significant gaps remain in the mechanisms and substrates underlying treatment-mediated recovery (rehabilitation, transplantation, and pharmacology). Development of successful multifaceted treatment paradigms applicable to people with SCI will require enhancing our knowledge of the mechanisms targeted by both the individual and combined therapeutic regimens. The windows of opportunity for application of one or more of these interventional strategies will also need to be assessed.

\section{CONCLUSIONS}

The adult mammalian CNS is capable of considerable spontaneous structural and functional plasticity, both in health and disease. Significant evidence from both human and animal studies indicates that rehabilitation strategies exploit this plasticity to promote recovery. Furthermore, rehabilitative strategies are not limited to targeting activity-dependent plasticity of the spinal cord below an injury but appear to promote plasticity in both cortical and descending pathways. While our understanding of rehabilitation-mediated activity-dependent plasticity after SCI has greatly increased, significant gaps remain and continued diligent research is required to optimize the effectiveness of rehabilitative interventions, given alone and as part of a multifaceted treatment approach.

\section{ACKNOWLEDGMENTS}

J. Lynskey and A. Belanger contributed equally to this effort. 
This material was based on work supported in part by the National Institutes of Health, National Center for Medical Rehabilitation Research, grant R01HD40335 to Ranu Jung.

The authors have declared that no competing interests exist.

\section{REFERENCES}

1. Thuret S, Moon LD, Gage FH. Therapeutic interventions after spinal cord injury. Nat Rev Neurosci. 2006;7(8): 628-43. [PMID: 16858391]

2. Ramer LM, Ramer MS, Steeves JD. Setting the stage for functional repair of spinal cord injuries: a cast of thousands. Spinal Cord. 2005;43(3):134-61. [PMID: 15672094]

3. Schwab ME. Bridging the gap in spinal cord regeneration. Nat Med. 1996;2(9):976-77. [PMID: 8782452]

4. Dietz V, Harkema SJ. Locomotor activity in spinal cordinjured persons. J Appl Physiol. 2004;96(5):1954-60. [PMID: 15075315]

5. Beekhuizen KS, Field-Fote EC. Massed practice versus massed practice with stimulation: effects on upper extremity function and cortical plasticity in individuals with incomplete cervical spinal cord injury. Neurorehabil Neural Repair. 2005;19(1):33-45. [PMID: 15673842]

6. Behrman AL, Bowden MG, Nair PM. Neuroplasticity after spinal cord injury and training: an emerging paradigm shift in rehabilitation and walking recovery. Phys Ther. 2006;86(10):1406-25. [PMID: 17012645]

7. Dobkin B, Apple D, Barbeau H, Basso M, Behrman A, Deforge D, Ditunno J, Dudley G, Elashoff R, Fugate L, Harkema S, Saulino M, Scott M; Spinal Cord Injury Locomotor Trial Group. Weight-supported treadmill vs over-ground training for walking after acute incomplete SCI. Neurology. 2006;66(4):484-93. [PMID: 16505299]

8. Wolpaw JR, Tennissen AM. Activity-dependent spinal cord plasticity in health and disease. Annu Rev Neurosci. 2001;24:807-43. [PMID: 11520919]

9. Dobkin BH. Neurobiology of rehabilitation. Ann N Y Acad Sci. 2004;1038:148-70. [PMID: 15838110]

10. Edgerton VR, Tillakaratne NJ, Bigbee AJ, De Leon RD, Roy RR. Plasticity of the spinal neural circuitry after injury. Annu Rev Neurosci. 2004;27:145-67. [PMID: 15217329]

11. Lawrence DG, Kuypers HG. The functional organization of the motor system in the monkey. I. The effects of bilateral pyramidal lesions. Brain. 1968;91(1):1-14. [PMID: 4966862]

12. Fouad K, Pedersen V, Schwab ME, Brösamle C. Cervical sprouting of corticospinal fibers after thoracic spinal cord injury accompanies shifts in evoked motor responses. Curr Biol. 2001;11(22):1766-70. [PMID: 11719218$]$

13. Raineteau O, Schwab ME. Plasticity of motor systems after incomplete spinal cord injury. Nat Rev Neurosci. 2001; 2(4):263-73. [PMID: 11283749]

14. Pettersson LG, Lundberg A, Alstermark B, Isa T, Tantisira B. Effect of spinal cord lesions on forelimb target-reaching and on visually guided switching of target-reaching in the cat. Neurosci Res. 1997;29(3):241-56.

\section{[PMID: 9436650]}

15. Weidner N, Ner A, Salimi N, Tuszynski MH. Spontaneous corticospinal axonal plasticity and functional recovery after adult central nervous system injury. Proc Natl Acad Sci U S A. 2001;98(6):3513-18. [PMID: 11248109]

16. Raineteau O, Fouad K, Noth P, Thallmair M, Schwab ME. Functional switch between motor tracts in the presence of the mAb IN-1 in the adult rat. Proc Natl Acad Sci U S A. 2001;98(12):6929-34. [PMID: 11381120]

17. Beattie MS, Bresnahan JC, Komon J, Tovar CA, Van Meter M, Anderson DK, Faden AI, Hsu CY, Noble LJ, Salzman S, Young W. Endogenous repair after spinal cord contusion injuries in the rat. Exp Neurol. 1997;148(2):453-63. [PMID: 9417825]

18. Hill CE, Beattie MS, Bresnahan JC. Degeneration and sprouting of identified descending supraspinal axons after contusive spinal cord injury in the rat. Exp Neurol. 2001; 171(1):153-69. [PMID: 11520130]

19. Weaver LC, Verghese P, Bruce JC, Fehlings MG, Krenz NR, Marsh DR. Autonomic dysreflexia and primary afferent sprouting after clip-compression injury of the rat spinal cord. J Neurotrauma. 2001;18(10):1107-19. [PMID: 11686496]

20. Zai LJ, Wrathall JR. Cell proliferation and replacement following contusive spinal cord injury. Glia. 2005;50(3): 247-57. [PMID: 15739189]

21. Pike FH, Elsbern CA, McCulloch WS, Rizzolo A. Some observations on experimentally produced convulsions: The localization of the motor mechanisms from which the typical clonic movements of epilepsy arise. Am J Psychiatry. 1929;9:259-83.

22. Bareyre FM, Kerschensteiner M, Raineteau O, Mettenleiter TC, Weinmann O, Schwab ME. The injured spinal cord spontaneously forms a new intraspinal circuit in adult rats. Nat Neurosci. 2004;7(3):269-77. [PMID: 14966523]

23. Von Euler M, Janson AM, Larsen JO, Seiger A, Forno L, Bunge MB, Sundström E. Spontaneous axonal regeneration in rodent spinal cord after ischemic injury. J Neuropathol Exp Neurol. 2002;61(1):64-75. [PMID: 11829345]

24. Zai LJ, Yoo S, Wrathall JR. Increased growth factor expression and cell proliferation after contusive spinal cord injury. Brain Res. 2005;1052(2):147-55. [PMID: 16005441] 
25. Green JB, Sora E, Bialy Y, Ricamato A, Thatcher RW. Cortical sensorimotor reorganization after spinal cord injury: an electroencephalographic study. Neurology. 1998; 50(4):1115-21. [PMID: 9566404]

26. Cohen LG, Bandinelli S, Topka HR, Fuhr P, Roth BJ, Hallett M. Topographic maps of human motor cortex in normal and pathological conditions: Mirror movements, amputations and spinal cord injuries. Electroencephalogr Clin Neurophysiol Suppl. 1991;43:36-50.

[PMID: 1773774]

27. Green JB, Sora E, Bialy Y, Ricamato A, Thatcher RW. Cortical motor reorganization after paraplegia: an EEG study. Neurology. 1999;53(4):736-43. [PMID: 10489034]

28. Nudo RJ. Plasticity. NeuroRx. 2006;3(4):420-27. [PMID: 17012055]

29. Kim BG, Dai HN, McAtee M, Vicini S, Bregman BS. Remodeling of synaptic structures in the motor cortex following spinal cord injury. Exp Neurol. 2006;198(2):401-15. [PMID: 16443221]

30. Bose P, Parmer R, Reier PJ, Thompson FJ. Morphological changes of the soleus motoneuron pool in chronic midthoracic contused rats. Exp Neurol. 2005;191(1):13-23. [PMID: 15589508]

31. Kitzman P. Alteration in axial motoneuronal morphology in the spinal cord injured spastic rat. Exp Neurol. 2005; 192(1):100-108. [PMID: 15698623]

32. Gazula VR, Roberts M, Luzzio C, Jawad AF, Kalb RG. Effects of limb exercise after spinal cord injury on motor neuron dendrite structure. J Comp Neurol. 2004;476(2): 130-45. [PMID: 15248194]

33. Van Ooyen A, Duijnhouwer J, Remme MW, Van Pelt J. The effect of dendritic topology on firing patterns in model neurons. Network. 2002;13(3):311-25. [PMID: 12222816]

34. London M, Häusser M. Dendritic computation. Annu Rev Neurosci. 2005;28:503-32. [PMID: 16033324]

35. Thompson FJ, Parmer R, Reier PJ. Alteration in rate modulation of reflexes to lumbar motoneurons after midthoracic spinal cord injury in the rat. I. Contusion injury. J Neurotrauma. 1998;15(7):495-508. [PMID: 9674553]

36. Chen Y, Chen XY, Jakeman LB, Chen L, Stokes BT, Wolpaw JR. Operant conditioning of H-reflex can correct a locomotor abnormality after spinal cord injury in rats. J Neurosci. 2006;26(48):12537-43. [PMID: 17135415]

37. Beaumont E, Houlé JD, Peterson CA, Gardiner PF. Passive exercise and fetal spinal cord transplant both help to restore motoneuronal properties after spinal cord transection in rats. Muscle Nerve. 2004;29(2):234-42. [PMID: 14755488]

38. Bennett DJ, Li Y, Harvey PJ, Gorassini M. Evidence for plateau potentials in tail motoneurons of awake chronic spinal rats with spasticity. J Neurophysiol. 2001;86(4): 1972-82. [PMID: 11600654]
39. Bennett DJ, Sanelli L, Cooke CL, Harvey PJ, Gorassini MA. Spastic long-lasting reflexes in the awake rat after sacral spinal cord injury. J Neurophysiol. 2004;91(5):2247-58. [PMID: 15069102]

40. Wong ST, Atkinson BA, Weaver LC. Confocal microscopic analysis reveals sprouting of primary afferent fibres in rat dorsal horn after spinal cord injury. Neurosci Lett. 2000;296(2-3):65-68. [PMID: 11108982]

41. Krenz NR, Weaver LC. Sprouting of primary afferent fibers after spinal cord transection in the rat. Neuroscience. 1998;85(2):443-58. [PMID: 9622243]

42. Hagg T, Oudega M. Degenerative and spontaneous regenerative processes after spinal cord injury. J Neurotrauma. 2006;23(3-4):264-80. [PMID: 16629615]

43. Nithianantharajah J, Hannan AJ. Enriched environments, experience-dependent plasticity and disorders of the nervous system. Nat Rev Neurosci. 2006;7(9):697-709. [PMID: 16924259]

44. Barbeau H, Fung J, Leroux A, Ladouceur M. A review of the adaptability and recovery of locomotion after spinal cord injury. Prog Brain Res. 2002;137:9-25.

[PMID: 12440356]

45. Dietz V. Human neuronal control of automatic functional movements: interaction between central programs and afferent input. Physiol Rev. 1992;72(1):33-69.

[PMID: 1731372]

46. Kandel E, Schwartz J, Jessel T. Principles of neuroscience. 4th ed. New York (NY): McGraw Hill Publishers; 2000. p. 730-31.

47. Skinner RD, Houle JD, Reese NB, Berry CL, Garcia-Rill E. Effects of exercise and fetal spinal cord implants on the H-reflex in chronically spinalized adult rats. Brain Res. 1996;729(1):127-31. [PMID: 8874885]

48. Hornby TG, Zemon DH, Campbell D. Robotic-assisted, body-weight-supported treadmill training in individuals following motor incomplete spinal cord injury. Phys Ther. 2005;85(1):52-66. [PMID: 15623362]

49. Reese NB, Skinner RD, Mitchell D, Yates C, Barnes CN, Kiser TS, Garcia-Rill E. Restoration of frequencydependent depression of the H-reflex by passive exercise in spinal rats. Spinal Cord. 2006;44(1):28-34.

[PMID: 16044168]

50. Kiser TS, Reese NB, Maresh T, Hearn S, Yates C, Skinner RD, Pait TG, Garcia-Rill E. Use of a motorized bicycle exercise trainer to normalize frequency-dependent habituation of the H-reflex in spinal cord injury. J Spinal Cord Med. 2005;28(3):241-45. [PMID: 16048142]

51. Rösche J, Paulus C, Maisch U, Kaspar A, Mauch E, Kornhuber $\mathrm{HH}$. The effects of therapy on spasticity utilizing a motorized exercise-cycle. Spinal Cord. 1997;35(3):176-78. [PMID: 9076869] 
52. Duysens J, Trippel M, Horstmann GA, Dietz V. Gating and reversal of reflexes in ankle muscles during human walking. Exp Brain Res. 1990;82(2):351-58. [PMID: 2286237]

53. Prochazka A, Gillard D, Bennett DJ. Positive force feedback control of muscles. J Neurophysiol. 1997;77(6): 3226-36. [PMID: 9212270]

54. Rossignol S, Bouyer L, Langlet C, Barthélemy D, Chau C, Giroux N, Brustein E, Marcoux J, Leblond H, Reader TA. Determinants of locomotor recovery after spinal injury in the cat. Prog Brain Res. 2004;143:163-72. [PMID: 14653161]

55. Barbeau H, McCrea DA, O’Donovan MJ, Rossignol S, Grill WM, Lemay MA. Tapping into spinal circuits to restore motor function. Brain Res Brain Res Rev. 1999; 30(1):27-51. [PMID: 10407124]

56. Van Meeteren NL, Eggers R, Lankhorst AJ, Gispen WH, Hamers FP. Locomotor recovery after spinal cord contusion injury in rats is improved by spontaneous exercise. J Neurotrauma. 2003;20(10):1029-37. [PMID: 14588119]

57. Hutchinson J, Gómez-Pinilla F, Crowe MJ, Ying Z, Basso DM. Three exercise paradigms differentially improve sensory recovery after spinal cord contusion in rats. Brain. 2004;127(Pt 6):1403-14. [PMID: 15069022]

58. Edgerton VR, Roy RR. Paralysis recovery in humans and model systems. Curr Opin Neurobiol. 2002;12(6):658-67. [PMID: 12490256]

59. Thota A, Carlson S, Jung R. Recovery of locomotor function after treadmill training of incomplete spinal cord injured rats. Biomed Sci Instrum. 2001;37:63-67. [PMID: 11347446]

60. De Leon RD, Hodgson JA, Roy RR, Edgerton VR. Locomotor capacity attributable to step training versus spontaneous recovery after spinalization in adult cats. J Neurophysiol. 1998;79(3):1329-40. [PMID: 9497414]

61. De Leon RD, Hodgson JA, Roy RR, Edgerton VR. Retention of hindlimb stepping ability in adult spinal cats after the cessation of step training. J Neurophysiol. 1999;81(1): 85-94. [PMID: 9914269]

62. Tillakaratne NJ, De Leon RD, Hoang TX, Roy RR, Edgerton VR, Tobin AJ. Use-dependent modulation of inhibitory capacity in the feline lumbar spinal cord. J Neurosci. 2002;22(8):3130-43. [PMID: 11943816]

63. Dietz V, Wirz M, Curt A, Colombo G. Locomotor pattern in paraplegic patients: training effects and recovery of spinal cord function. Spinal Cord. 1998;36(6):380-90. [PMID: 9648193]

64. Wernig A, Müller S, Nanassy A, Cagol E. Laufband therapy based on "rules of spinal locomotion" is effective in spinal cord injured persons. Eur J Neurosci. 1995;7(4): 823-29. [PMID: 7620630]

65. Wernig A, Nanassy A, Müller S. Maintenance of locomotor abilities following Laufband (treadmill) therapy in para- and tetraplegic persons: follow-up studies. Spinal Cord. 1998;36(11):744-49. [PMID: 9848480]

66. Wernig A, Nanassy A, Müller S. Laufband (LB) therapy in spinal cord lesioned persons. Prog Brain Res. 2000; 128:89-97. [PMID: 11105671]

67. McDonald JW, Becker D, Sadowsky CL, Jane JA Sr, Conturo TE, Schultz LM. Late recovery following spinal cord injury. Case report and review of the literature. J Neurosurg. 2002;97(2 Suppl):252-65. [PMID: 12296690]

68. Behrman AL, Harkema SJ. Locomotor training after human spinal cord injury: a series of case studies. Phys Ther. 2000;80(7):688-700. [PMID: 10869131]

69. Behrman AL, Lawless-Dixon AR, Davis SB, Bowden MG, Nair P, Phadke C, Hannold EM, Plummer P, Harkema SJ. Locomotor training progression and outcomes after incomplete spinal cord injury. Phys Ther. 2005;85(12): 1356-71. [PMID: 16305274]

70. Hoffman LR, Field-Fote EC. Cortical reorganization following bimanual training and somatosensory stimulation in cervical spinal cord injury: A case report. Phys Ther. 2007;87(2):208-23. [PMID: 17213410]

71. Winchester P, McColl R, Querry R, Foreman N, Mosby J, Tansey K, Williamson J. Changes in supraspinal activation patterns following robotic locomotor therapy in motor-incomplete spinal cord injury. Neurorehabil Neural Repair. 2005;19(4):313-24. [PMID: 16263963]

72. Jackson A, Mavoori J, Fetz EE. Long-term motor cortex plasticity induced by an electronic neural implant. Nature. 2006;444(7115):56-60. [PMID: 17057705]

73. Thomas SL, Gorassini MA. Increases in corticospinal tract function by treadmill training after incomplete spinal cord injury. J Neurophysiol. 2005;94(4):2844-55.

[PMID: 16000519]

74. Norton JA, Gorassini MA. Changes in cortically related intermuscular coherence accompanying improvements in locomotor skills in incomplete spinal cord injury. J Neurophysiol. 2006;95(4):2580-89. [PMID: 16407422]

75. Lankhorst AJ, Ter Laak MP, Van Laar TJ, Van Meeteren NL, De Groot JC, Schrama LH, Hamers FP, Gispen WH. Effects of enriched housing on functional recovery after spinal cord contusive injury in the adult rat. J Neurotrauma. 2001;18(2):203-15. [PMID: 11229712]

76. Hamers FP, Lankhorst AJ, Van Laar TJ, Veldhuis WB, Gispen WH. Automated quantitative gait analysis during overground locomotion in the rat: its application to spinal cord contusion and transection injuries. J Neurotrauma. 2001;18(2):187-201. [PMID: 11229711]

77. Brock TO, O'Callaghan JP. Quantitative changes in the synaptic vesicle proteins synapsin I and p38 and the astrocyte-specific protein glial fibrillary acidic protein are associated with chemical-induced injury to the rat central 
nervous system. J Neurosci. 1987;7(4):931-42.

[PMID: 3106588]

78. Wang T, Xie K, Lu B. Neurotrophins promote maturation of developing neuromuscular synapses. J Neurosci. 1995; 15(7 Pt 1):4796-4805. [PMID: 7623111]

79. Dupont-Versteegden EE, Houlé JD, Dennis RA, Zhang J, Knox M, Wagoner G, Peterson CA. Exercise-induced gene expression in soleus muscle is dependent on time after spinal cord injury in rats. Muscle Nerve. 2004;29(1): 73-81. [PMID: 14694501]

80. Gómez-Pinilla F, Ying Z, Roy RR, Molteni R, Edgerton VR. Voluntary exercise induces a BDNF-mediated mechanism that promotes neuroplasticity. J Neurophysiol. 2002; 88(5):2187-95. [PMID: 12424260]

81. Koliatsos VE, Clatterbuck RE, Winslow JW, Cayouette $\mathrm{MH}$, Price DL. Evidence that brain-derived neurotrophic factor is a trophic factor for motor neurons in vivo. Neuron. 1993;10(3):359-67. [PMID: 8080464]

82. Lu P, Jones LL, Snyder EY, Tuszynski MH. Neural stem cells constitutively secrete neurotrophic factors and promote extensive host axonal growth after spinal cord injury. Exp Neurol. 2003;181(2):115-29.

[PMID: 12781986]

83. Buck CR, Seburn KL, Cope TC. Neurotrophin expression by spinal motoneurons in adult and developing rats. J Comp Neurol. 2000;416(3):309-18. [PMID: 10602090]

84. Zing Z, Roy RR, Edgerton VR, Gómez-Pinilla F. Exercise restores levels of neurotrophins and synaptic plasticity following spinal cord injury. Exp Neurol. 2005;193(2): 411-19. [PMID: 15869943]

85. Vaynman S, Ying Z, Gómez-Pinilla F. Exercise induces BDNF and synapsin I to specific hippocampal subfields. J Neurosci Res. 2004;76(3):356-62. [PMID: 15079864]

86. Gómez-Pinilla F, Ying Z, Opazo P, Roy RR, Edgerton VR. Differential regulation by exercise of BDNF and NT3 in rat spinal cord and skeletal muscle. Eur J Neurosci. 2001; 13(6):1078-84. [PMID: 11285004]

87. Skup M, Dwornik A, Macias M, Sulejczak D, Wiater M, Czarkowska-Bauch J. Long-term locomotor training upregulates $\operatorname{TrkB}(\mathrm{FL})$ receptor-like proteins, brain-derived neurotrophic factor, and neurotrophin 4 with different topographies of expression in oligodendroglia and neurons in the spinal cord. Exp Neurol. 2002;176(1):289-307. [PMID: 12359171]

88. Ying Z, Roy RR, Edgerton VR, Gómez-Pinilla F. Voluntary exercise increases neurotrophin-3 and its receptor TrkC in the spinal cord. Brain Res. 2003;987(1):93-99. [PMID: 14499950]

89. Venkatasubramanian G, Jung R, Sweeney J. Functional electrical stimulation. In: Webster JG, editor. Encyclopedia of medical devices and instrumentation. Vol 3. Hoboken (NJ): Wiley-Interscience; 2006. p. 347-66.
90. Field-Fote EC. Combined use of body weight support, functional electric stimulation, and treadmill training to improve walking ability in individuals with chronic incomplete spinal cord injury. Arch Phys Med Rehabil. 2001;82(6):818-24. [PMID: 11387589]

91. Abbas JJ, Gillette JC. Using electrical stimulation to control standing posture. IEEE Cont Syst Mag. 2001;21(4): 80-90.

92. Riess J, Abbas JJ. Adaptive neural network control of cyclic movements using functional neuromuscular stimulation. IEEE Trans Rehabil Eng. 2000;8(1):42-52. [PMID: 10779107]

93. Peckham PH, Creasey GH. Neural prostheses: clinical applications of functional electrical stimulation in spinal cord injury. Paraplegia. 1992;30(2):96-101.[PMID: 1589297]

94. Stein RB, Chong SL, James KB, Kido A, Bell GJ, Tubman LA, Bélanger M. Electrical stimulation for therapy and mobility after spinal cord injury. Prog Brain Res. 2002;137: 27-34. [PMID: 12440357]

95. Abbas JJ, Triolo RJ. Experimental evaluation of an adaptive feedforward controller for use in functional neuromuscular stimulation systems. IEEE Trans Rehabil Eng. 1997;5(1):12-22. [PMID: 9086381]

96. Herman R, He J, D’Luzansky S, Willis W, Dilli S. Spinal cord stimulation facilitates functional walking in a chronic, incomplete spinal cord injured. Spinal Cord. 2002;40(2): 65-68. [PMID: 11926417]

97. Maiman DJ, Mykleburst JB, Barolat-Romana G. Spinal cord stimulation for amelioration of spasticity: experimental results. Neurosurgery. 1987;21(3):331-33. [PMID: 3499582]

98. Pinter MM, Gerstenbrand F, Dimitrijevic MR. Epidural electrical stimulation of posterior structures of the human lumbosacral cord: 3. Control of spasticity. Spinal Cord. 2000;38(9):524-31. [PMID: 11035472]

99. Field-Fote EC. Spinal cord stimulation facilitates functional walking in a chronic, incomplete spinal cord injured subject. Spinal Cord. 2002;40(8):428. [PMID: 12124674] Comment in: Herman R, He J, D’Luzansky S, Willis W, Dilli S. Spinal Cord. 2002;40(2):65-68.

[PMID: 11926417]

100. Field-Fote EC, Tepavac D. Improved intralimb coordination in people with incomplete spinal cord injury following training with body weight support and electrical stimulation. Phys Ther. 2002;82(7):707-15. [PMID: 12088467]

101. Postans NJ, Hasler JP, Granat MH, Maxwell DJ. Functional electric stimulation to augment partial weight-bearing supported treadmill training for patients with acute incomplete spinal cord injury: A pilot study. Arch Phys Med Rehabil. 2004;85(4):604-10. [PMID: 15083437] 
102. Barbeau H, Ladouceur M, Mirbagheri MM, Kearney RE. The effect of locomotor training combined with functional electrical stimulation in chronic spinal cord injured subjects: walking and reflex studies. Brain Res Brain Res Rev. 2002;40(1-3):274-91. [PMID: 12589926]

103. Bajd T, Kralj A, Stefancic M, Lavrac N. Use of functional electrical stimulation in the lower extremities of incomplete spinal cord injured patients. Artif Organs. 1999;23(5):403-9. [PMID: 10378929]

104. Thrasher TA, Flett HM, Popovic MR. Gait training regimen for incomplete spinal cord injury using functional electrical stimulation. Spinal Cord. 2006;44(6):357-61. [PMID: 16249784$]$

105. Dobkin BH. Do electrically stimulated sensory inputs and movements lead to long-term plasticity and rehabilitation gains? Curr Opin Neurol. 2003;16(6):685-91. [PMID: 14624077]

106. Stein RB, Gordon T, Jefferson J, Sharfenberger A, Yang JF, De Zepetnek JT, Belanger M. Optimal stimulation of paralyzed muscle after human spinal cord injury. J Appl Physiol. 1992;72(4):1393-1400. [PMID: 1317372$]$

107. Martin TP, Stein RB, Hoeppner PH, Reid DC. Influence of electrical stimulation on the morphological and metabolic properties of paralyzed muscle. J Appl Physiol. 1992;72(4):1401-6. [PMID: 1534322]

108. Bélanger M, Stein RB, Wheeler GD, Gordon T, Leduc B. Electrical stimulation: Can it increase muscle strength and reverse osteopenia in spinal cord injured individuals? Arch Phys Med Rehabil. 2000;81(8):1090-98.

[PMID: 10943761]

109. Page SJ, Levine P, Strayer J. An electric stimulation cycling protocol for gait in incomplete spinal cord injury. Arch Phys Med Rehabil. 2007;88(6):798-800. [PMID: 17532906]

110. Donaldson N, Perkins TA, Fitzwater R, Wood DE, Middleton F. FES cycling may promote recovery of leg function after incomplete spinal cord injury. Spinal Cord. 2000; 38(11):680-82. [PMID: 11114775]

111. Stites EC, Abbas JJ. Sensitivity and versatility of an adaptive system for controlling cyclic movements using functional neuromuscular stimulation. IEEE Trans Biomed Eng. 2000;47(9):1287-92. [PMID: 11008432]

112. Riess J, Abbas JJ. Adaptive control of cyclic movements as muscles fatigue using functional neuromuscular stimulation. IEEE Trans Neural Syst Rehabil Eng. 2001;9(3): 326-30. [PMID: 11561670]

113. Ezenwa BN, Glaser RM, Couch W, Figoni SF, Rodgers MM. Adaptive control of functional neuromuscular stimulation-induced knee extension exercise. J Rehabil Res Dev. 1991;28(4):1-8. [PMID: 1941644$]$
114. North RB, Wetzel FT. Spinal cord stimulation for chronic pain of spinal origin: a valuable long-term solution. Spine. 2002;27(22):2584-92. [PMID: 12435997]

115. Lavrov I, Gerasimenko YP, Ichiyama RM, Courtine G, Zhong H, Roy RR, Edgerton VR. Plasticity of spinal cord reflexes after a complete transection in adult rats: relationship to stepping ability. J Neurophysiol. 2006;96(4): 1699-1710. [PMID: 16823028]

116. Carhart MR, He J, Herman R, D’Luzansky S, Willis WT. Epidural spinal-cord stimulation facilitates recovery of functional walking following incomplete spinal-cord injury. IEEE Trans Neural Syst Rehabil Eng. 2004;12(1): 32-42. [PMID: 15068185]

117. Minassian K, Persy I, Rattay F, Pinter MM, Kern H, Dimitrijevic MR. Human lumbar cord circuitries can be activated by extrinsic tonic input to generate locomotor-like activity. Hum Mov Sci. 2007;26(2):275-95.

[PMID: 17343947]

118. Minassian K, Jilge B, Rattay F, Pinter MM, Binder H, Gerstenbrand F, Dimitrijevic MR. Stepping-like movements in humans with complete spinal cord injury induced by epidural stimulation of the lumbar cord: electromyographic study of compound muscle action potentials. Spinal Cord. 2004;42(7):401-16. [PMID: 15124000]

119. Ichiyama RM, Gerasimenko YP, Zhong H, Roy RR, Edgerton VR. Hindlimb stepping movements in complete spinal rats induced by epidural spinal cord stimulation. Neurosci Lett. 2005;383(3):339-44. [PMID: 15878636]

120. Gerasimenko YP, Avelev VD, Nikitin OA, Lavrov IA. Initiation of locomotor activity in spinal cats by epidural stimulation of the spinal cord. Neurosci Behav Physiol. 2003;33(3):247-54. [PMID: 12762591]

121. Gauthier L, Rossignol S. Contralateral hindlimb responses to cutaneous stimulation during locomotion in high decerebrate cats. Brain Res. 1981;207(2):303-20. [PMID: 7470911]

122. Gossard JP, Cabelquen JM, Rossignol S. Phase-dependent modulation of primary afferent depolarization in single cutaneous primary afferents evoked by peripheral stimulation during fictive locomotion in the cat. Brain Res. 1990;537(1-2):14-23. [PMID: 2085768]

123. Huang H, He J, Herman R, Carhart MR. Modulation effects of epidural spinal cord stimulation on muscle activities during walking. IEEE Trans Neural Syst Rehabil Eng. 2006;14(1):14-23. [PMID: 16562627]

124. Cai LL, Courtine G, Fong AJ, Burdick JW, Roy RR, Edgerton VR. Plasticity of functional connectivity in the adult spinal cord. Philos Trans R Soc Lond B Biol Sci. 2006; 361(1473):1635-46. [PMID: 16939979]

125. Simpson RK Jr, Robertson CS, Goodman JC. Segmental recovery of amino acid neurotransmitters during posterior 
epidural stimulation after spinal cord injury. J Am Paraplegia Soc. 1993;16(1):34-41. [PMID: 8093898]

126. Petrakis IE, Sciacca V. Epidural spinal cord electrical stimulation in diabetic critical lower limb ischemia. J Diabetes Complications. 1999;13(5-6):293-99. [PMID: 10765005]

127. Hosobuchi Y. Electrical stimulation of the cervical spinal cord increases cerebral blood flow in humans. Appl Neurophysiol. 1985;48(1-6):372-76. [PMID: 3879799$]$

128. Visocchi M. Spinal cord stimulation and cerebral haemodynamics. Acta Neurochir Suppl. 2006;99:111-16. [PMID: 17370775]

129. Al-Majed AA, Brushart TM, Gordon T. Electrical stimulation accelerates and increases expression of BDNF and trkB mRNA in regenerating rat femoral motoneurons. Eur J Neurosci. 2000;12(12):4381-90. [PMID: 11122348]

130. Al-Majed AA, Tam SL, Gordon T. Electrical stimulation accelerates and enhances expression of regenerationassociated genes in regenerating rat femoral motoneurons. Cell Mol Neurobiol. 2004;24(3):379-402. [PMID: 15206821]

131. Al-Majed AA, Neumann CM, Brushart TM, Gordon T. Brief electrical stimulation promotes the speed and accuracy of motor axonal regeneration. J Neurosci. 2000; 20(7):2602-8. [PMID: 10729340]

132. Balkowiec A, Katz DM. Activity-dependent release of endogenous brain-derived neurotrophic factor from primary sensory neurons detected by ELISA in situ. J Neurosci. 2000;20(19):7417-23. [PMID: 11007900]

133. Knikou M, Conway BA. Effects of electrically induced muscle contraction on flexion reflex in human spinal cord injury. Spinal Cord. 2005;43(11):640-48. [PMID: 15968304]

134. Lee JK, Emch GS, Johnson CS, Wrathall JR. Effect of spinal cord injury severity on alterations of the H-reflex. Exp Neurol. 2005;196(2):430-40. [PMID: 16185689]
135. Kanchiku T, Lynskey JV, Protas D, Abbas JJ, Jung R. Neuromuscular electrical stimulation induced forelimb movement in a rodent model. J Neurosci Methods. 2008; 167(2):317-26. [PMID: 17870182]

136. Ichihara K, Venkatasubramanian G, Abbas JJ, Jung R. Electrical stimulation paradigms to assist in locomotor training after spinal cord injury [abstract]. J Neurotrauma. 2003;20(10):1131.

137. Jung R, Belanger A, Kanchiku T, Lynskey J, Mukherjee M, Hagner D, Abbas JJ. Hindlimb neuromuscular stimulation therapy after thoracic contusion injury promotes locomotor recovery. In: 2006 Proceedings of the 11th Annual Conference of the International Functional Electrical Stimulation Society (IFESS); 12-14 Sep 2006; MiyagiZao, Japan. Glendale (CA): IFESS; 2007.

138. Yoshihara H, Shumsky JS, Neuhuber B, Otsuka T, Fischer I, Murray M. Combining motor training with transplantation of rat bone marrow stromal cells does not improve repair or recovery in rats with thoracic contusion injuries. Brain Res. 2006;1119(1):65-75. [PMID: 17027672]

139. Harvey PJ, Grochmal J, Tetzlaff W, Gordon T, Bennett DJ. An investigation into the potential for activity-dependent regeneration of the rubrospinal tract after spinal cord injury. Eur J Neurosci. 2005;22(12):3025-35. [PMID: 16367769]

140. De Leon RD, Acosta CN. Effect of robotic-assisted treadmill training and chronic quipazine treatment on hindlimb stepping in spinally transected rats. J Neurotrauma. 2006; 23(7):1147-63. [PMID: 16866627]

Submitted for publication March 18, 2007. Accepted in revised form August 7, 2007. 